\title{
PELATIHAN PENYUSUNAN LAPORAN KEUANGAN PADA BADAN USAHA MILIK NAGARI MITRA PALALUAR MADANI
}

\author{
Indrayeni $^{1)}$, Fitria Rahmi' ${ }^{1)}$, Rahmaita ${ }^{1)}$ \\ 1)Universitas Dharma Andalas \\ Email: inka_yeni@yahoo.com; fitriazulkarnain@gmail.com; tata_neeed@yahoo.com
}

\begin{abstract}
ABSTRAK
Badan usaha milik nagari dibangun untuk meningkatkan perekonomian masyarakat yang terdapat di pedesaan. Hal tersebut tertuang dalam UU No 6 Tahun 2014 tentang Desa pasal 23, bahwa badan usaha ini didirikan untuk memenuhi kebutuhan usaha-usaha skala mikro yang dijalankan oleh pelaku usaha ekonomi desa. Badan Usaha Milik Nagari Mitra Palaluar Madani didirikan untuk menjawab kebutuhan ini. BUMNag Mitra Palaluar Madani merupakan badan usaha yang bergerak dibidang keuangan dengan memberikan kredit berupa simpan pinjam kepada pelaku bisnis mikro yang terdapat di daerah Palaluar. Pelatihan penyusunan laporan keuangan pada Bumnag Mitra Palaluar Madani dilakukan untuk membantu menyediakan informasi yang andal bagi pihak-pihak yang berkepentingan terhadap Bumnag tersebut sebagai bentuk akuntabilitas publik. Laporan keuangan yang harus disediakan berupa neraca, laporan laba rugi, laporan perubahan ekuitas, laporan arus kas dan catatan atas laporan keuangan. Kegiatan pelatihan ini telah diikuti oleh peserta sebanyak 14 orang. Kegiatan ini dilakukan memberikan pelatihan tentang penyusunan laproan keuangan yang baik sesuai dengan standar akuntansi yang berlaku yaitu SAK ETAP. Selama pelatihan diketahui bahwa laporan keuangan yang disusun oleh Bumnag belum berdasarkan standar yang berlaku. Disamping itu, laporan keuangan yang dibuat hanya laporan laba rugi dan neraca, sedangkan laporan arus kas dan laporan perubahan ekuitas belum dibuat oleh Bumnag tersebut.
\end{abstract}

Kata kunci: akuntabilitas, laporan keuangan, BUMNag

\section{ABSTRACT}

Small-Medium Entity was built to improve the economy of the people in rural areas. This is stated in UU No. 6 of 2014 concerning Village article 23, that business entity was established to meet the needs of micro-scale businesses run by village economic business actors. BUMNag Mitra Palaluar Madani established to answer this needs. BUMNag Mitra Palaluar Madani is a business entity engaged in finance by providing credit in the savings and loans to micro businesses in the Palaluar area. Training on the preparation of financial reports at the BUMNag Palaluar Madani was carried out to help provide reliable information to those interested in the Bumnag as a form of public accountability. The financial statements that must be provided are balance sheets, income statements, equity statement, cash flow and notes to financial statements. This training activity attended by 14 participants. This activity was carried out to provide training on preparation of financial statements in accordance with accounting standards, namely SAK ETAP. During the training, it was found that the financial statements prepared by the Bumnag were not based on the applicable standards. Besides of that, the financial statements made are only income statements, while the cash flow statement and changes in equity have not been made by Bumnag.

Key words: accountability, financial statement, BUMNag 


\section{PENDAHULUAN}

Desa merupakan satu kesatuan masyarakat hukum yang memiliki batas wilayah yang mengatus mengatur dan mengurus kepentingan masyarakat. Untuk dapat mengakomodir segala kepentingan dan kebutuhan masyarakat desa, maka disahkanlah UU Nomor 6 Tahun 2014 tentang Desa. Undang - undang ini mengamanatkan agar pemerintah desa lebih mandiri dalam mengelola pemerintahan dan berbagai sumber daya alam yang dimiliki, termasuk didalamnya pengelolaan keuangan dan kekayaan milik desa.

Pemberian kesempatan yang lebih besar bagi desa untuk mengurus tata pemerintahannya sendiri serta pemerataan pelaksanaan pembangunan, diharapkan dapat meningkatkan kesejahteraan dan kualitas hidup masyarakat desa, sehingga permasalahan seperti kesenjangan antar wilayah, kemiskinan, dan masalah sosial budaya lainnya dapat diminimalisir. Selain Dana Desa, sesuai UU Desa pasal 72, Desa memiliki Pendapatan Asli Desa dan Pendapatan Transfer berupa Alokasi Dana Desa; Bagian dari Hasil Pajak dan Retribusi Kabupaten/Kota; dan Bantuan Keuangan dari APBD Provinsi/ Kabupaten/Kota Peran besar yang diterima oleh desa. Oleh karena itu pemerintah desa harus bisa menerapkan prinsip akuntabilitas dalam tata pemerintahannya, dimana semua akhir kegiatan penyelenggaraan pemerintahan desa harus dapat dipertanggungjawabkan kepada masyarakat desa sesuai dengan ketentuan yang berlaku.

Dalam hal keuangan desa, pemerintah desa wajib menyusun Laporan Realisasi Pelaksanaan APB Desa dan Laporan Pertanggungjawaban Realisasi Pelaksanaan APBDesa. Laporan ini dihasilkan dari suatu siklus pengelolaan keuangan desa, yang dimulai dari tahapan perencanaan dan penganggaran; pelaksanaan dan penatausahaan; hingga pelaporan dan pertanggungjawaban pengelolaan keuangan desa.

Berdasarkan Permendes PDTT tersebut, maka Desa atau "Nagari" dapat mendirikan Badan Usaha Milik Desa (BUMDes) atau BUMNag untuk Sumatera Barat, melalui Peraturan Nagari (PERNA), dengan tujuan, diantaranya adalah meningkatkan perekonomian Nagari, meningkatkan pendapatan masyarakat dan pendapatan asli Nagari, meningkatkan pengelolaan potensi Nagari sesuai dengan kebutuhan masyarakat yang bermuara kepada peningkatan kesejahteraan masyarakat. Badan Usaha Milik Nagari adalah perwujudan dari pengelolaan ekonomi produktif nagari yang dilakukan secara kooperatif, partisipatif, emansipatif, serta transparansi. Oleh karena itu perlu upaya serius untuk menjadikan pengelolaan BUMNag dapat berjalan secara mandiri, efektif, efisien dan profesional.

Dalam tahap perencanaan dan penganggaran, pemerintah desa harus melibatkan masyarakat desa yang direpresentasikan oleh Badan Permusyarakatan Desa (BPD), sehingga program kerja dan kegiatan yang disusun dapat mengakomodir kepentingan dan kebutuhan masyarakat desa serta sesuai dengan kemampuan yang dimiliki oleh desa tersebut. Selain itu pemerintah desa harus bisa menyelenggarakan pencatatan atau pembukuan atas transaksi keuangannya sebagai wujud pertanggungjawab keuangan yang dilakukan.

Untuk mewujudkan kualitas akuntabilitas yang lebih baik, perlu adanya sumber daya manusia yang memadai dan dukungan sarana dan prasarana dalam pengelolaan keuangan. Disamping itu, masih banyak masyarakat desa yang belum kritis dalam pengelolaan anggaran pendapatan dan belanja desa. Oleh karena itu, diperlukannya pendampingan dalam perencanaan, pelaksanaan dan pemantauan pembangunan desa. Pendampingan ini dapat dilakukan dalam bentuk memberikan pelatihan, bimtek dan 
workshop tentang pengelolaan keuangan desa sehingga meningkatkan pemahaman aparatur desa dalam pengelolaan keuangan desa sehingga juga akan meningkatkan kualitas laporan keuangan desa.

Penyusunan laporan keuangan bagi badan usaha milik nagari bertujuan untuk mengetahui perkembangan usaha. Perkembangan usaha dapat diketahui dari laba yang diperoleh selama usaha berjalan. Disamping itu, laporan keuangan juga dapat digunakan untuk mengetahui penggunaan dana desa dan jumlah persediaan yang dimilki. Dari sumber informasi yang diperoleh, diketahui bahwa masih banyaknya aparat desa yang tidak memahami cara membuat laporan keuangan yang sesuai dengan ketentuan yang berlaku. Oleh karena itu, dalam rangka kegiatan pengabdian kepada masyarakat, penulis ingin membantu pengelola badan usaha yang ada di desa dalam menyusun laporan keuangan.

\section{TINJAUAN PUSTAKA}

Menurut SAK ETAP, tujuan laporan keuangan adalah untuk memberikan informasi tentang posisi keuangan, kinerja dan arus kas perusahaan yang bermanfaat bagi sebagian besar pengguna laporan untuk membuat keputusan ekonomi dan menunjukkan pertanggungjawaban (stewardship) manajemen atas penggunaan sumber daya yang dipercayakan kepada mereka. Untuk mencapai tujuan ini, laporan keuangan memberikan informasi tentang perusahaan yang meliputi: asset, liabilitas, ekuitas, pendapatan dan beban dan arus kas. Laporan keuangan menunjukkan hasil pertanggungjawaban manajemen atas penggunaan sumber daya yang telah dipercayakan kepada mereka. Laporan Keuangan yang disusun manajemen biasanya terdiri dari:

1. Laporan posisi keuangan, yaitu laporan yang menunjukkan posisi keuangan suatu perusahaan pada suatu tanggal tertentu

2. Laporan laba rugi, yaitu laporan yang menunjukkan hasil usaha dan biaya-biaya selama periode tertentu

3. Laporan perubahan ekuitas, yaitu laporan yang menunjukkan sebab-sebab perubahan modal dari jumlah pada awal periode menjadi jumlah modal pada akhir periode

4. Laporan arus kas, menunjukkan arus arus kas keluar dan kas masuk, serta pengaruhnya terhadap saldo kas akhir periode.

5. Catatan atas laporan keuangan, yaitu menjelaskan informasi secara rinci atau detail yang dianggap perlu terhadap laporan keuangan yang ada.

Menurut Standar Akuntansi Keuangan ETAP (IAI; 2012), laporan keuangan yang berguna bagi pengguna informasi, harus memiliki karakteristik kualitatif, yaitu:

1. Dapat Dipahami

Kualitas penting informasi yang diajikan dalam laporan keuangan adalah kemudahannya untuk segera dipahami oleh pengguna. Pengguna yang dimaskud adalah masyarakat yang mengerti tentang ekonomi dan keuangan.

2. Relevan

Informasi memiliki kualitas relevan jika dapat mempengaruhi keputusan ekonomi pengguna dengan cara membantu mereka mengevaluasi peristiwa masa lalu, masa kini atau masa depan, menegaskan, atau mengoreksi hasil evaluasi dimasa lalu.

3. Materialitas 
Informasi dipandang material jika kelalaian untuk mencantumkan atau kesalahan dalam mencatat informasi tersebut dapat mempengaruhi keputusan ekonomi pengguna yang diambil atas dasar laporan keuangan.

4. Andal

Informasi memiliki kualitas andal jika bebsan dari kesalahan material dan penyajian secara jujur apa yang seharusnya diajikan atau yang secara wajar diharpkan dapat disajikan

5. Pertimbangan sehat

Pertimbangan sehat mengandung unsur kehati-hatian pada saat melakukan pertimbangan yang diperlukan dalam kondisi ketidakpastian, sehingga aset atau penghasilan tidak disajikan lebih tinggi dan kewajiban atau beban tidak disajikan lebih rendah.

6. Kelengkapan

Agar dapat diandalkan, informasi dalam laporan keuangan harus lengkap dalam batasan materialitas dan biaya, kesengajaan untuk tidak mengungkapkan mengakibatkan informasi menjadi tidak benar atau menyesatkan dan karena itu tidak dapat diandalkan dan kurang mencukupi ditinjau dari segi relevansi.

7. Dapat dibandingkan

Pengguna harus mampu membandingkan laporan keuangan entitas antar periode untuk mengidentifikasi kecenderungan posisi dan kinerja keuangan. Pengguna juga dapat membandingan laporan keuangan antar entitas untuk mengevaluasi posisi keuangan secara relatif.

Menurut Warsono dkk (2010), siklus akuntansi keuangan terdiri dari 2 kelompok waktu, yaitu sub-siklus selama periode berjalan dan sub-siklus pada akhir periode. Berdasarkan jenis kegiatannya, silkus akuntansi selama periode berjalan dapat diklasifikasikan 2 kelompok: kegiatan penyiapan transaksi dan kegiatan pencatatan transaksi. Aktivitas di siklus akuntansi akhir periode dapat dikelompokkan menjadi 2 (dua) yaitu aktivitas pencatatan transaksi dan aktivitas penyusunan laporan keuangan.

Secara garis besar, ada empat istilah umum akuntansi yang digunakan dalam pembukuan BUMNag, yakni: Harta, Hutang, Biaya, dan Pendapatan.

- Harta dalam pengertian akuntansi adalah semua barang dan hak milik BUMNag dan sumber ekonomi lainnya. Harta BUMNag dapat dibedakan menjadi tiga macam yakni harta tetap, harta lancar, dan harta tidak berwujud.

- Hutang merupakan kewajiban yang harus dibayar pada masa mendatang (sesuai dengan kesepakatan yang dibuat) akibat dari suatu transaksi. Berdasarkan waktu pembayaran, hutang dapat dibedakan menjadi dua yaitu hutang jangka pendek dan hutang jangka panjang.

- Pendapatan adalah peningkatan harta/aktiva perusahaan sebagai akibat terjadinya transaksi yang menguntungkan.

- Biaya adalah harta yang digunakan untuk menghasilkan pendapatan dalam satu periode tertentu yang habis terpakai. Terdapat tiga jenis biaya yang umumnya harus dibayar oleh BUMNag yaitu: Harga Pokok Penjualan, Biaya operasi dan Biaya lain-lain.

Pada prinsipnya akuntansi merupakan sebuah sistem yang mengolah transaksi menjadi informasi keuangan. Menurut Warsono dkk (2008), akuntansi merupakan 
proses sistematis untuk mengolah transaksi menjadi informasi keuangan yang bermanfaat bagi para penggunanya. Akuntansi terdiri dari 3 (tiga) komponen utama, yaitu:

1. Input berupa peristiwa binis yang bersifat keuangan (transaksi)

2. Proses terdiri dari berbagai kegiatan untuk mengolah input akuntansi, seperti penjurnalan dan pemindahbukuan.

3. Output berupa informasi keuangan.

Definisi akuntansi dapat juga dilihat dari gambar dibawah ini:

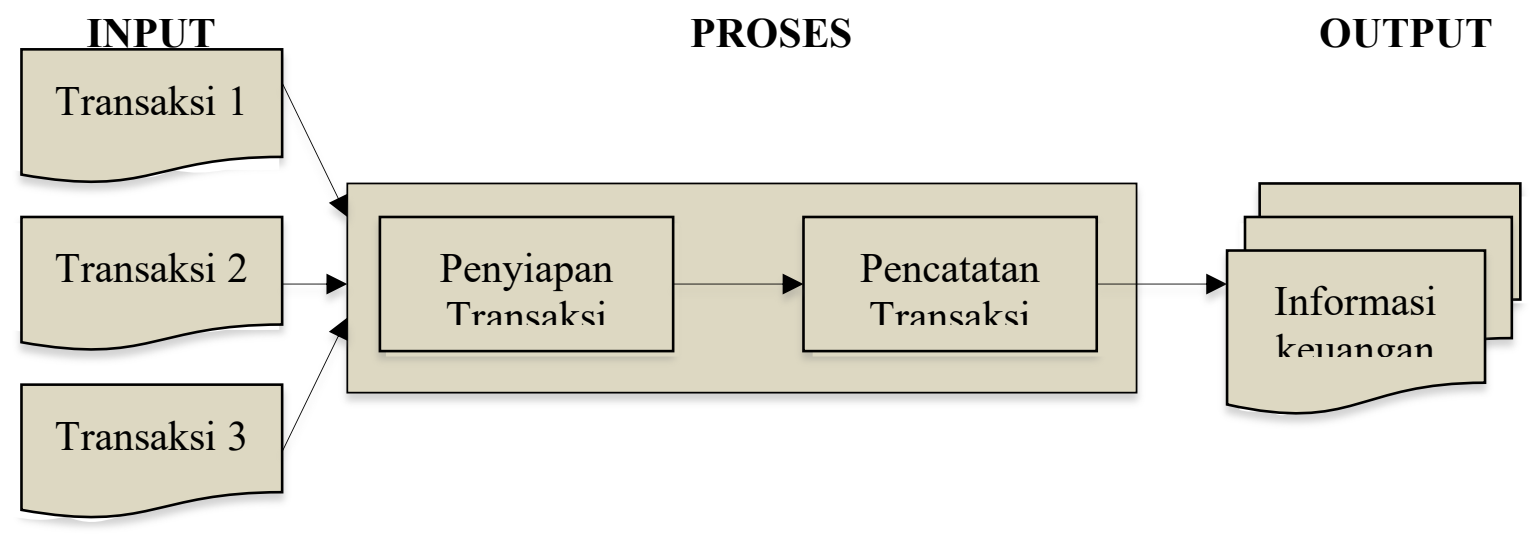

Sumber: Warsono dkk (2010).

Gambar 1 Definisi Akuntansi

Informasi akuntansi dapat digunakan oleh berbagai pihak baik dari dalam maupun luar perusahaan. Dalam perusahaan bisa manajer, karyawan, sedangkan luar perusahaan dapat kreditor, pemerintah, pelanggan, pemasok dan serikat kerja. Informasi keuangan ini akan dimanfaatkan oleh penggunanya untuk memenuhi kepentingannya masing - masing. Sebagai contoh, pemilik menggunakan informasi keuangan untuk menilai perkembangan modal yang telah disetorkan, kreditor membutuhkan informasi keuangan untuk menilai kemampuan perusahaan melunasi pinjaman, dan manajer menggunakannya untuk mengetahui kinerjanya dalam mengelola perusahaan.

Menurut Warsono dkk (2010), akuntansi dapat dianalogikan dengan produk teknologi seperti komputer, pesawat terbang, dan sebagainya. Akuntansi dirancang untuk memenuhi kebutuhan manusia berupa informasi keuangan. Dengan demikian, sebagai alat yang dibutuhkan tersebut, maka akuntansi harus berlandaskan pada 3 pilar, yaitu pengetahuan yang mapan, prinsip-prinsip dasar dan rancang bangun. Pengetahuan yang mapan mengacu pada persamaan akuntansi yang mengacu pada persamaan matematika, yaitu penggunaan dana sama dengan pemerolehan dana. Penggunaan dana dapat berupa asset, biaya dan pengembalian modal, sedangkan pemerolehan dana dapat bersumber dari utang, ekuitas sendiri dan pendapatan yang dihasilkan. Pilar kedua bahwa akuntansi mengacu pada prinsip-prinsip yang berlaku umum (PABU). Prinsip akuntansi yang berterima umum merupakan standar akuntansi yang digunakan sebagai pedoman dalam menyusun laporan keuangan. Pada pilar yang ketiga bahwa sebagai sebuah sistem akuntansi harus dirancang-bangun secara sistematis agar informasi keuangan dapat tersedia seacra efektif dan efisien. 
Siklus akuntansi diawali dengan mengidentifikasi transaksi ekonomi. Suatu transaksi disebut transaksi ekonomi jika transaksi tersebut bersifat keuangan dan menyebabkan perubahan di elemen-elemen laporan keuangan. Setelah diidentifikasi, transaksi akan didokumentasikan dalam bukti traksaksi untuk dicatat dalam jurnal. Transaksi harus dicatat secara sistematis dan mencantumkan informasi-informasi penting untuk proses akuntansi. Hasil penjurnalan yang baik akan menjadikan badan usaha dapat mengetahui besaran dan jenis-jenis transaksi yang terjadi dengan mudah.

Pencatatan akuntansi setelah melakukan penjurnalan adalah pemindahbukuan. Pemindahbukuan merupakan kegiatan memindahkan akun-akun yang tercantum di buku jurnal ke akun-akun yang sama di buku besar. Pemindahbukuan dapat dilakukan secara periodik misalnya per akhir hari/minggu/bulan, ataupun seketika pada saat penjurnalan transaksi diselesaikan. Informasi penting yang ada di buku jurnal lazimnya juga disertakan dalam pemindahbukuan tersebut. Pada akhir periode siklus akuntansi, terdapat dua aktivitas yang harus dilakukan, yaitu membuat jurnal penyesuaian dan menyusun laporan keuangan. Jurnal penyesuaian dilakukan agar laporan keuangan menyajikan informasi yang sesungguhnya. Selain itu, jurnal penyesuaian dilakukan untuk menghindari adanya kesalahan dalam pencatatan selama periode berjalan dan baru diketahui ketika akan menyusun laporan keuangan.

Laporan keuangan dapat disusun melalui kertas kerja (neraca lajur). Pembuatan kertas kerja ini merupakan salah satu media pendukung dalam membuat laporan keuangan tahunan. Saldo - saldo yang terdapat pada neraca saldo dipindahkan ke dalam neraca lajur untuk dibuatkan penyesuaiannya. Jurnal penyesuaian dibuat untuk menyesuaikan akun-akun agar menyajikan informasi yang sesungguhnya. Menurut Warsono dkk (2010), terdapat 4 jenis kesalahan pencatatan yang mungkin terjadi dalam akuntansi, yaitu lupa mencatat transaksi, salah akun, salah nilai moneter dan kombinasi salah akun dan nilai moneter. Koreksi dilakukan dengan menganalisis dampak kesalahannya. Setelah membuat jurnal penyesuaian, maka dibuatlah Daftar Saldo Setelah Penyesuaian. Berdasarkan Daftar Saldo Setelah Penyusunan ini, laporan keuangan dapat disusun. Penyusunan laporan keuangan dapat dimulai dari laporan laba rugi, laporan perubahan ekuitas, laporan posisi keuangan dan laporan arus kas.

\section{METODE PELAKSANAAN}

Khalayak sasaran dari pengabdian ini adalah Kepala Desa, Perangkat Desa Lainnya, Pengelola BUMNag serta wakil masyarakat Desa. Untuk efektifitas pelaksanaan pelatihan serta untuk mencapai tujuan dan manfaat pelaksanaan pengabdian masyarakat ini, maka sasaran difokuskan pada pengelola bumnang. Disamping itu, Kepala Desa dan perangkatnya juga dapat mengikuti kegiatan ini. Hal ini dilakukan karena pihak-pihak tersebut diatas adalah pihak yang akan secara langsung mengawasi dan menjalankan serta bertanggung jawab terhadap kemajuan BUMNag.

Metode kegiatan pengabdian kepada masyarakat ini dilakukan dalam bentuk pelatihan penyusunan laporan keuangan bagi pengurus atau perangkat desa lainnya. Adapun tahapan kegiatan yang akan dilaksanakan adalah peserta diberikan materi pelatihan tentang penyusunan laporan keuangan dengan menyiapkan narasumber yang kompeten dan relevan dengan materi yang disiapkan dan peserta diberikan soal latihan untuk mengaplikasikan apa yang telah disampaikan oleh narasumber.

\section{HASIL DAN PEMBAHASAN}


Badan Usaha Miliki Nagari didirikan dengan tujuan untuk dapat membantu nagari dalam menyelenggarakan cabang-cabang produksi yang penting bagi nagari dan menguasai hajat hidup orang banyak. Hasil usaha yang diperoleh oleh nagari digunakan untuk pengembangan usaha, pembangunan nagari, pemberdayaan masyarakat dan membantu masyarakat miskin dengan memberikan hibah, bantuan sosial dan kegiatan dana bergulir yang ditetapkan dalam Anggaran Pendapatan dan Belanja Desa.

Badan Usaha Milik Nagari (BUMNag) Mitra Palaluar Madani Kabupaten Sijunjung telah didirikan sejak tahun 2016. BUMNag ini telah membantu menggerakkan perekonomian Palaluar dengan mengembangkan unit-unit usaha yang dapat membantu masyarakat di nagari tersebut. Kegiatan usaha utama yang dilakukan oleh BUMNag Mitra Palaluar Madani ini berupa jasa keuangan dan perdagangan umum. Jasa keuangan yang diberikan berupa simpan pinjam syariah, sedangkan perdagangan umum berupa dealer motor, arisan motor syariah, perabotan dan elektornik serta loket pembayaran online (PPOB).

Dalam rangka meningkatkan kemampuan masyarakat dalam mengendalikan perekonomian di desa, maka BUMNag Mitra Palaluar Madani berencana akan memperluas kegiatan usahanya. Adapun kegiatan usaha yang akan dilaksanakan adalah dengan mendirikan Bank Mini, Toserba, memproduksi dan menjual Closet serta menjadi agen/pangkalan LPG $3 \mathrm{~kg}$. Disamping itu, Bumnag Mitra Palaluar Madani ini juga akan bergerak ke bidang pertanian/peternakan berupa budidaya pertanian/peternakan/ikan dan jual beli hasil tani/ternak/ikan.

Sebagai lembaga keuangan desa yang menjalankan bisnis keuangan, Bumnag Mitra Palaluar Madani wajib membuat laporan keuangan bagi seluruh unit-unit usaha BUMNag dengan jujur dan transparan. Disamping itu, BUMNag juga wajib memberikan laporan perkembangan unit-unit usahanya kepada masyarakat melalui musyawarah desa sekurang-kurangnya dua kali dalam satu tahun.

Badan usaha milik desa/nagari merupakan badan usaha yang modalnya berasal dari dana desa. Menurut Undang - undang Nomor 6 Tahun 2014 Tentang Desa, menyatakan bahwa BUMDes merupakan badan usaha yang sebagian besar modalnya dimiliki oleh desa melalui penyertaan secara langsung yang berasal dari kekayaan desa yang dipisahkan. Untuk dapat menentukan terlaksananya akuntansi yang baik, maka laporan keuangan badan usaha milik nagari telah menyusun laporan keuangannya sesuai dengan standar akuntansi yang berlaku yaitu Standar Akuntansi Keuangan Entitas Tanpa Akuntabilitas Publik (SAK ETAP).

Proses pencatatan untuk BUMNag bisa dilakukan dengan sistem yang diterapkan dalam akuntansi sederhana, yakni dengan membuat dan mengumpulkan bukti transaksi, seperti kwitansi, nota atau bon pembelian maupun penjualan. Dari mengumpulkan bukti transaksi kemudian menyusun buku kas harian atau arus kas ke dalam bentuk buku kas harian. Dari Buku Kas Harian ini dapat diketahui berapa besarnya uang masuk dan keluar serta saldo atau sisa dana dalam setiap harinya. Untuk memudahkan penggunaan buku harian kas diperlukan membuat sebuah kelompok rekening yang akan memudahkan pengguna laporan keuangan dalam membuat, mengelompokkan dan menyusun pembukuan. Apabila BUMNag mengalami perkembangan sehingga transaksinya bertambah banyak setiap harinya, maka pembukuannya dapat ditambah dengan membuat laporan neraca saldo dan laporan keuangan.

Laporan laba rugi digunakan untuk mengukur kinerja Bumnag selama satu periode. Dengan semakin besarnya laba yang diperoleh, maka semakin baik kinerja 
Bumnag tersebut. Laba yang diperoleh oleh BUMNag akan dibagikan kepada Desa sebagai penyertaan modal. Laba rugi yang diperoleh oleh Bumnag merupakan elemen ekuitas. Laba akan menyebabkan terjadi kenaikan ekuitas, sedangkan rugi akan menyebabkan penurunan ekuitas. Laporan perubahan ekuitas sangat penting untuk mengetahui perkembangan modal yang telah disetorkan. Laporan posisi keuangan (neraca) menunjukkan jumlah asset, utang dan ekuitas pada tanggal tertentu. Asset akan disusun berdasarkan likuiditasnya. Pada dasarnya asset akan dibagi atas dua, yaitu asset lancar dan asset nonlancar. Utang akan disusun berdasarkan waktu pelunasannya, mulai dari utang jangka pendek sampai utang jangka panjang. Kelompok ekuitas akan disusun setelah akun utang.

Laporan arus kas menyajikan informasi tentang sumber dan penggunaan kas selama satu periode. Sumber dan penggunaan kas ini dibagi ke dalam tiga jenis aktivitas, yaitu aktivitas operasi, aktivitas investasi dan aktivitas pendanaan. Aktivitas operasi merupakan aktivitas yang berasal dari kegiatan operasi Bumnag. Aktivitas investasi meliputi transaksi - transaksi yang berkaitan dengan pembelian dan penjualan asset untuk investasi. Dan aktivitas pendanaan berkaitan dengan transaksi - transaksi pemerolehan dan penggunaan dana Bumnag.

Dalam rangka menghasilkan laporan keuangan yang andal dan dipercaya, maka diadakan pelatihan penyusunan laporan keuangan pada Badan Usaha Milik Nagari Mitra Palaluar Madani. Pelatihan ini diikuti oleh beberapa pengelola BUMNag yang terdapat di desa Palaluar. Pelatihan dilakukan dalam bentuk ceramah kepada peserta pelatihan.

Berikut dokumentasi kegiatan pelatihan penyusunan laporan keuangan pada Bumnag Mitra Palaluar Madani:

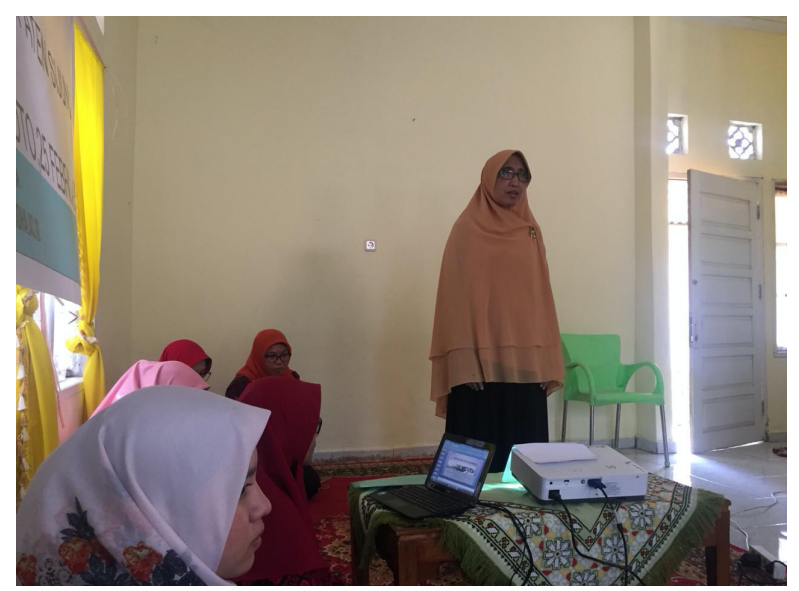

Gambar 2 Penyampaian Materi 


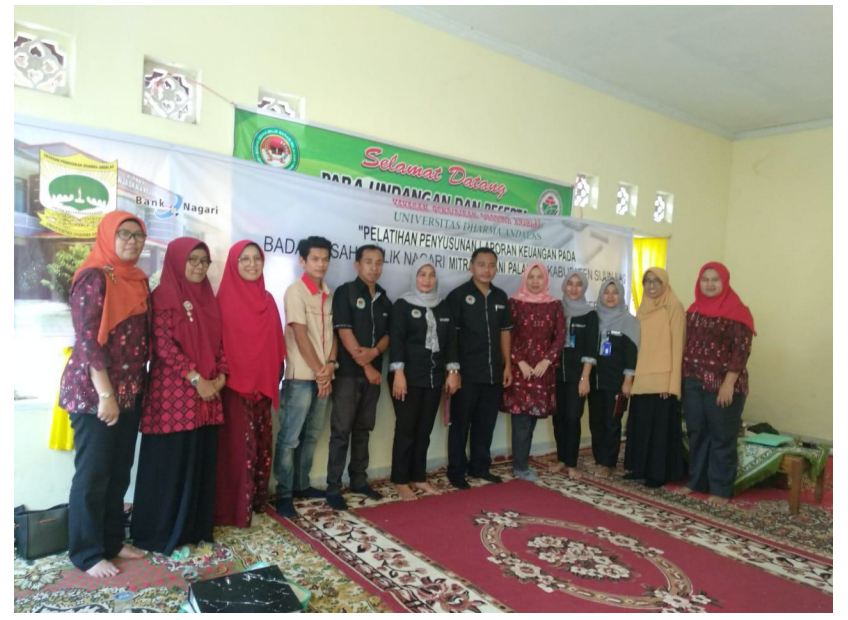

Gambar 3. Direktur BUMNag Mitra Palaluar dan Tim Unidha

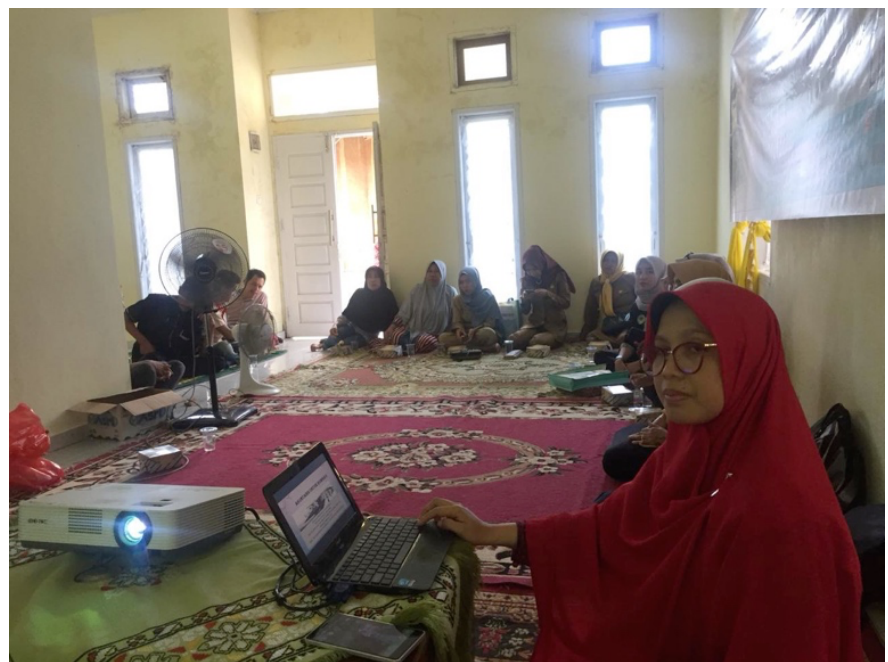

Gambar 4. Pelatihan Penyusunan Laporan Keuangan

BUMNag Mitra Palaluar telah membuat laporan keuangan untuk pertanggujawaban, namun masih sangat sederhana. Transaksi yang dicatat masih dalam bentuk manual. Setiap bukti dikumpulkan dengan membuat file bukti berdasarkan tanggal terjadinya. Dari bukti ini pengelola membuatkan jurnalnya setiap akhir periode. Dalam pembuatan jurnal, BUMNag sudah menggunakan debit dan kredit, namun pengelola mencatat setiap transaksi setiap akhir periode (bulanan), sehingga memungkinkan terjadinya kesalahan dalam pencatatan.

BUMNag Mitra Palaluar tidak melakukan posting untuk jurnal yang telah dibuatnya. BUMNag ini meringkas berbagai jenis perkiraan dengan menggunakan jurnal memorial, dimana kita hanya mengetahui jumlah keseluruhan dari debit dan kredit dan tidak berdasarkan akun perkiraannya. Dalam akuntansi, untuk mengetahui jumlah saldo setiap perkiraan sangat penting sehingga memudahkan untuk membuat kertas kerja atau neraca lajur. Neraca lajur merupakan salah satu media yang dapat digunakan untuk menyusun laporan keuangan. Dalam menyusun laporan keuangan, BUMNag Mitra Palaluar hanya menggunakan neraca sederhana yang berisikan saldo awal setiap perkiraan dan mutasi yang terjadi sehingga diketahui saldo akhirnya. Saldo akhir ini yang akan digunakan untuk menyusun laporan keuangan oleh Bumnag Mitra 
Palaluar. Laporan keuangan yang dibuat oleh BUMNag hanya terdiri dari laporan laba rugi dan laporan posisi keuangan.

Dalam membuat laporan posisi keuangan, BUMNag Mitra Palaluar sudah memisahkan asset, liabilitas dan ekuitas. Namun demikian, BUMNag belum melakukan penyusutan untuk setiap asset tetapnya. Berdasarkan SAK ETAP, setiap asset tetap harus disajikan jumlah akumulasi penyusutannya sehingga bisa diketahui berapa jumlah neto untuk setiap asset yang digunakan. Untuk itu, BUMNag Mitra Palaluar harus menghitung kembali jumlah penyusutan untuk setiap asset tetap yang dimilikinya.

Untuk menghasilkan laporan keuangan yang berkualitas, sangat penting bagi BUMNag untuk memberikan pelatihan bagi pengelolanya dalam menyusun laporan keuangan sesuai dengan standar akuntansi keuangan yang berlaku saat ini, yaitu Standar Akuntansi Keuangan ETAP (SAK ETAP).

\section{KESIMPULAN}

Berdasarkan hasil kegiatan pelatihan penyusunan laporan keuangan pada Badan Usaha Milik Nagari Mitra Palaluar Madani Kabupaten Sijunjung, maka dapat disimpulkan bahwa BUMNag Mitra Palaluar belum menyusun laporan keuangannya sesuai dengan standar akuntansi yang berlaku umum (SAK ETAP). Disamping itu, bumang belum melakukan posting untuk setiap akun perkiraannya sehingga sulit diketahui jumlah saldo akhirnya. Bumnag Mitra Palaluar, hanya menyusun dua jenis laporan keuangan, yaitu laporan posisi keuangan dan laporan laba.

Berdasarkan hasil kegiatan yang telah dilaksanakan, dapat disarankan agar pengelola Bumnag dapat memberikan pelatihan-pelatihan/bimbingan teknis kepada pegawainya terutama bagian akuntansi agar dapat menyusun laporan keuangan sesuai dengan standar akuntansi yang berlaku.

\section{DAFTAR PUSTAKA}

[1]. Deputi Bidang Pengawasan Penyelenggaraan Keuangan Daerah. 2015. Petunjuk Pelaksanaan Bimbingan dan Konsultasi Pengelolaan Keuangan Desa. BPKP. Jakarta.

[2]. Ikatan Akuntan Indonesia. 2013. Standar Akuntansi Keuangan Entitas Tanpa Akuntabilitas Publik. Jakarta: Salemba Empat.

Desa. Jakarta: IAI-KASP.

2015. Pedoman Asistensi Akuntansi Keuangan

[4]. Rudini, Nurhayati, dan Afriyanto. 2015. Analisa Penerapan SAK ETAP Pada Badan Usaha Milik Desa (BUMDes) Langkitin di Desa Langkitin. Universitas Pasir Pengaraian.

[5]. Undang-Undang Nomor 6 Tahun 2014 Tentang Desa.

[6]. Warsono, Sony, Sagoro, Endra Murti. Darmawan Arif, dan Ridha, M. Arsyadi. 2010. Akuntansi UMKM Ternyata Mudah Dipahami dan Dipraktekan. Asgrad Chapter. Yogyakarta. 